\title{
Russia's Contract Arbitrage
}

Anna Gelpern

Georgetown University Law Center, ag1348@law.georgetown.edu

This paper can be downloaded free of charge from:

https://scholarship.law.georgetown.edu/facpub/1448

http://ssrn.com/abstract=2557376

\section{Cap. Markets L.J. (forthcoming)}

This open-access article is brought to you by the Georgetown Law Library. Posted with permission of the author. Follow this and additional works at: https://scholarship.law.georgetown.edu/facpub

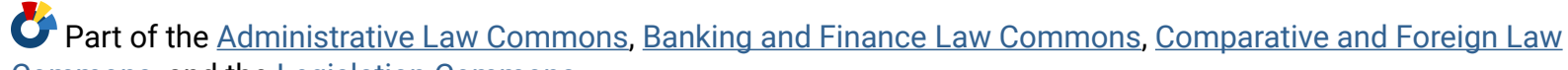
Commons, and the Legislation Commons 


\title{
Russia's Contract Arbitrage
}

\author{
Anna Gelpern ${ }^{1}$
}

\begin{abstract}
:
Ukraine is poised to restructure its debt, but Russia may hold the best cards in the negotiation. Russia bought $\$ 3$ billion in Ukrainian eurobonds in late 2013 to prop up a political ally, sincedeposed. As Russian President Vladimir Putin himself has pointed out, these bonds have unique terms that let Russia call for early repayment, putting it ahead of Ukraine's private creditors. Meanwhile, Russia and its proxies hold enough bonds to block a restructuring vote or hold out, sticking more losses on other creditors. Russia has refused to restructure the bonds in the Paris Club of government-to-government creditors, claiming that they are commercial debt. In all, Russia has effectively arbitraged the prevailing sovereign debt regime, where public and private lending to sovereigns are separated by legal form and restructuring institutions. Because the bonds in question are governed by English law, the U.K. Parliament can limit the scope for abuse by making them unenforceable. Such legislation has ample precedent, and would compare favorably to traditional sanctions. Uniquely among sanctions, it would not only punish Russia, but could deliver immediate financial relief for Ukraine.
\end{abstract}

Ukraine has two debt problems. First, it faces shrinking revenues, rising costs, and a spike in foreign debt payments over the next two years. This is a common problem, easily managed with familiar market tools and international institutions. Ukraine's other debt problem is less common and hardly manageable: its leading bond holder is annexing parts of its territory and stoking militant separatists from within.

Together the two debt problems reveal a gap in the international financial architecture. The system is set up as if market finance and political patronage were distinct, for reasons having as much to do with administrative convenience as with ideological conviction. When governments participate as debtors or creditors in the global capital markets, they are expected to use private deal technology, and abide by the rules and incentives of these markets. When governments put on their power-political hats, they are expected to retreat to political fora, removed from the markets. Being sovereign, they do not have to.

\footnotetext{
${ }^{1}$ Georgetown Law and Peterson Institute for International Economics. I am grateful to Anders Åslund, Will Chamberlain, Mitu Gulati, Adam Levitin, Douglas A. Rediker, Jeffrey J.Schott, Brad Setser, Edwin M. Truman, and Ángel Ubide for comments. A more recent policy brief based on the article is here.
} 
Russia put itself in a position to arbitrage the gap when it structured a \$3 billion loan to gain advantage over Ukraine's private and public creditors alike. It lent the money to prop up an ally, Ukrainian President Viktor Yanukovych, who was deposed two months later. The unusual debt contracts were designed to keep Ukraine "on a tight leash." The bonds were scheduled to mature in only two years, and gave Russia broad latitude to demand early repayment, trigger default, hold out in a debt restructuring, and sabotage any debt negotiations that might accompany Ukraine's territorial break-up. Meanwhile, Russia stands to reap more than any other bondholder from the International Monetary Fund (IMF) program for Ukraine, which unlocked $\$ 33$ billion in donor funds through 2016.

Since the key $\$ 3$ billion contract is governed by English law, the simplest way to neutralize it would be for the U.K. Parliament to pass a law making the bond unenforceable. Debt sanctions of this sort would not preclude Ukraine from paying Russia as part of a political settlement. But without sanctions, Russia could profit financially and politically from its arbitrage of the private contract form, tainting the London market and the English courts.

Going forward, narrowly drawn debt sanctions could fill a gap in the international system. These might prevent parties from entering into abusive contracts to begin with-or prevent them from enforcing existing contracts abusively. Properly designed, they can promote more effective sanctions and a sovereign debt regime that is both more just and more efficient.

\section{A Manageable Debt ${ }^{2}$}

Ukraine's debt looks modest compared to Euro area crisis countries, which had captured sovereign debt headlines for the past four years. In early 2014, Ukraine reported its public debt stock at just over $\$ 73$ billion, including $\$ 13$ billion in state guarantees for Naftogaz (the state gas monopoly), the state infrastructure fund, and others. The government and the IMF estimated public debt at slightly above 40 per cent of Ukraine's gross domestic product (GDP) at the end of 2013; rising to over 63 per cent by 2015 partly thanks to an influx of multilateral loans for the new government. In contrast, Greece had zoomed past 150 per cent when it launched its debt restructuring. At the end of 2013, Ukraine's public external debt was slightly over half of its total public debt; foreign currency debt (including domestic debt in foreign currency) was almost 60 per cent of the total.

\footnotetext{
${ }^{2}$ Throughout this section, unless otherwise indicated, debt figures are drawn from the IMF program tables. See INT'L MONETARY FUnd, UKRAINE: REQUEST FOR A STAND-BY ARRANGEMENT-STAFF REPORT 36-39 tbl.2-4 (2014), available at http://www.imf.org/external/pubs/cat/longres.aspx?sk=41516.0; Ukraine, Bond ProspectusU.S. \$1,984,838,800 5.00 per cent Notes due 2015, pp. 137-58 (Feb. 17, 2014), http://www.centralbank.ie/regulation/securitiesmarkets/prospectus/Lists/ProspectusDocuments/Attachments/19034/Prospectus\%20-\%20Standalone\%20(3).pdf.
} 
In its $\$ 17$ billion initial program for Ukraine, the IMF concluded that government debt was "sustainable with high probability" despite risks from capital flight, shaky banks, and a fragile currency. This diagnosis had both analytical and practical significance. The two-year program stood at about 800 per cent of Ukraine's IMF quota, an exceptional level of financing that triggers additional debt scrutiny. IMF policy precludes it from lending more than twice the member's quota in one year unless the country's debt is sustainable with high probability. ${ }^{3}$ This requirement is understood to protect IMF resources and the chances of restoring the member's balance of payments. If debt is unsustainable, the IMF would expect the country to restructure it as a condition of support. When it approved the initial program, it did not ask Ukraine to restructure.

Any debt sustainability judgment for Ukraine was best viewed as provisional, subject to economic uncertainties as well as "uncertainties that come from geopolitics." First, quite apart from its conflict with Russia, Ukraine could not pay its debts in the near term without help from abroad. It reported owing over $\$ 10$ billion in principal and another $\$ 3.5$ billion in interest to foreign creditors before the end of 2015, and nearly \$21 billion more before the end of 2020 . (Table 1) Friendly governments and multilateral organizations stepped into the breach with over $\$ 30$ billion (Table 2), which was thought sufficient in the spring of 2014 to allow Ukraine to repay all the debts coming due and meet its other projected foreign currency needs through 2016. The plan was to come back to the capital markets in 2015 and 2016. In the long term, because most donor support came in the form of loans, it would add to Ukraine's debt stock and transform it from mostly private to mostly public.

\footnotetext{
${ }^{3}$ Other criteria for exceptional access are the country's exceptional balance of payments need, favorable prospects for accessing the private capital markets, and the likely success of the IMF program. The IMF's program in Greece established an exception to the access criteria to allow lending even when the member's debt is not sustainable with high probability, where there is high risk of international spillovers. See Int'l Monetary Fund, Greece: Ex Post Evaluation of Exceptional Access under the 2010 Stand-By Arrangement 1 (2013); 36 Int'l Monetary Fund, Selected Decisions and Selected Documents of the International Monetary Fund 456 (2011).

${ }^{4}$ Ian Talley, IMF Approves $\$ 17$ Billion Emergency Aid for Ukraine's Economy, Wall Street Journal, April 30, 2014, http://online.wsj.com/news/articles/SB10001424052702303948104579534140466543308.
} 
Table 1: Public External Debt Service

(US\$ million; Source: Ministry of Finance, Ukraine Prospectus dated February 17, 2014)

\begin{tabular}{|l|c|r|r|r|r|r|r|}
\hline & $\mathbf{2 0 1 4}$ & $\mathbf{2 0 1 5}$ & \multicolumn{1}{c|}{$\mathbf{2 0 1 6}$} & \multicolumn{1}{c|}{$\mathbf{2 0 1 7}$} & \multicolumn{1}{c|}{$\mathbf{2 0 1 8}$} & \multicolumn{1}{c|}{$\mathbf{2 0 1 9}$} & \multicolumn{1}{c|}{$\mathbf{2 0 2 0}$} \\
\hline Interest & 1607.4 & 1912.2 & 1790.8 & 896.7 & 596.3 & 588.9 & 580.3 \\
\hline Principal & 4267.5 & 5815.7 & 8759.1 & 4335.8 & 559.3 & 519.5 & 2054.9 \\
\hline Total & 5874.9 & 7727.9 & 10549.9 & 5232.5 & 1155.6 & 1108.4 & 2635.2 \\
\hline
\end{tabular}

Second, Ukraine has a spotty debt history, and a spotty history of performance under IMF programs. It last restructured its public debt in 2000, when it was under 60 per cent of its GDP. ${ }^{5}$ State-owned Naftogaz restructured its bonds in $2009 .{ }^{6}$ In addition, Ukraine's past programs with the IMF had routinely failed to deliver promised policy reform. ${ }^{7}$ History need not determine the future - the new government, eager to turn a new leaf, satisfied a number of difficult policy conditions before the first IMF disbursement - but history also cautions against over-reliance on magic numbers, such as the ratio of debt to GDP. Whether for external, institutional, or historical reasons, "living with debt" has not been Ukraine's strong suit. ${ }^{8}$

Table 2: Donor Pledges

(Source: IMF)

\begin{tabular}{|l|r|}
\hline \multicolumn{1}{|c|}{ Source } & \multicolumn{1}{|c|}{$\begin{array}{c}\text { Pledged for } \\
\text { 2014-2016 } \\
\text { (US\$ Billion) }\end{array}$} \\
\hline International Monetary Fund & 17.1 \\
\hline European Commission & 2.9 \\
\hline $\begin{array}{l}\text { European Bank for Reconstruction and } \\
\text { Development, European Investment Bank }\end{array}$ & 8.1 \\
\hline The World Bank & 3.9 \\
\hline United States & 1.0 \\
\hline Total & 33.0 \\
\hline
\end{tabular}

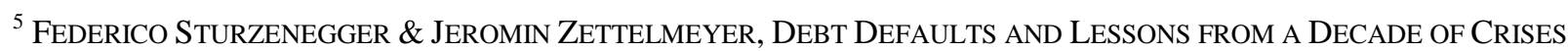
129 (2006) at 127.

${ }^{6}$ See Udaibir S. Das et al., Sovereign Debt Restructurings 1950-2010: Literature Survey, Data, and Stylized Facts 57 (IMF Working Paper No. 12/203, 2012), available at http://www.un.org/esa/ffd/ecosoc/debt/2013/IMF_wp12_203.pdf.

${ }^{7}$ See Int'l Monetary Fund, Ukraine and the IMF, http://www.imf.org/external/country/UKR/INDEX.htm (last visited May 7, 2014).

${ }^{8}$ See Eduardo Borensztein et al., Inter-American Development Bank, Living with Debt: How to Limit the Risks of Sovereign Finance 232 (2006); Carmen M. Reinhart et al., Debt Intolerance, 1 Brookings Papers on Econ. Activity 1,40 (2003).
} 
Third, Ukraine needs large amounts of hard currency to pay for energy imports. The IMF estimated Ukraine's gas imports at $\$ 36.5$ billion for 2011-2013, nearly all from Russia. When the two countries were on good terms, Ukraine got a discount on its gas bills. When they were not, Russia threatened to cut off gas supplies. Since the conflict began, Russia hiked the price and claimed billions of dollars in arrears, much of it disputed by Ukraine. While the dispute is in arbitration in Stockholm, Ukraine scrambles to find alternative suppliers and supply routes; meanwhile, the IMF estimated that gas payments would consume about $\$ 10$ billion per year for the foreseeable future, even if Ukraine implemented reforms to make its energy sector more efficient. Combined with a high level of foreign currency debt, this makes Ukraine vulnerable to exchange rate fluctuations as well as volatile energy prices. ${ }^{9}$

Fourth, with the eastern part of the country in violent turmoil, the size of Ukraine's economy and central government resources going forward is anyone's guess. The loss of Crimea and Sevastopol, which accounted for less than 5 per cent of Ukraine's GDP and relied on transfers from Kyiv, had a limited effect on economic forecasts. In contrast, the east and the south represent over 20 per cent of GDP, the bulk of its industry and exports. Even if the security crisis ended in autonomy rather than secession for these regions, the prospects of fiscal transfers to the center look dubious.

Fifth, the Russian government and state-owned firms hold over $\$ 5$ billion in Ukrainian bond claims by some estimates. ${ }^{10}$ This includes the $\$ 3$ billion issue highlighted in the introduction to this essay, which matures in December 2015 and represents by far the biggest bond payment due during the IMF program period. ${ }^{11}$ Even if Ukraine continues to pay this debt in full and on time, the contract terms enable Russia to demand early repayment, triggering a cascade of defaults. If Ukraine's economic situation deteriorates, or if its territory breaks up, the bonds are structured to give Russia extra leverage in any debt negotiations that might follow.

\section{Tainted Notes}

Viktor Yanukovych was a kleptocrat who ran a corrupt and ultimately violent government. Ukraine's outstanding government debt rose during his four-year term, while a tiny elite lived large off state favors. Yanukovych got a \$3 billion lifeline from Russian President Vladimir Putin in December 2013 to help keep him in power and reward him for turning away from an Association Agreement with the European Union. It did not work: Yanukovych was deposed and escaped to Russia three months later, after protests where government snipers are accused of

\footnotetext{
${ }^{9}$ Additional foreign currency demands may come from banks and non-financial firms that borrowed abroad. Because much of this borrowing was from foreign affiliates, it is more likely to roll over.

${ }^{10}$ See Dragon Capital, Ukrainian Economy: Public F/X Debt Service Schedule for 2014-1Q15 1 (2014).

${ }^{11}$ This does not include conventional government-to-government (Paris Club) claims, the arrears claimed by Gazprom, or Russian claims on private Ukrainian entities, which would contribute to the demands on foreign exchange reserves. Ukraine reported owing Russia a little over $\$ 700$ million in Paris Club debt.
} 
killing 100 people in one day. The debt became his parting gift to the people of Ukraine and an arbitrage opportunity for President Putin.

At the time, Ukraine ranked 144 out of 175 on the Transparency International Corruption Perception Index and 134 out of 142 on its Judicial Independence Index; it was in the $25^{\text {th }}$ percentile in the Rule of Law Index. ${ }^{12} \mathrm{~A}$ few oligarchs had controlled the country's industry since the post-Soviet privatizations of the 1990s, benefitting from broken tax and public procurement systems, as most people struggled to make ends meet. ${ }^{13}$ The former president faces charges of stealing tens of billions of dollars in public funds. One of his homes had a private zoo with $\$ 10,000$ name plates for the animals, paid by the state. ${ }^{14}$ Since Yanukovych's departure, prosecutors have begun the search for embezzled money scattered through shell companies, offshore trusts, and secret bank accounts around the world. ${ }^{15}$

Borrowing from Russia was nothing new for Ukraine, but this debt was different. It came in the form of tradable notes listed on the Irish Stock Exchange and governed by English law, indistinguishable in most ways from Ukraine's eleven other outstanding bond market issues. Government-to-government budget support normally takes the form of inter-governmental credit agreements, which do not trade in the private markets and are not meant to be enforced in court. When such credits run into trouble, creditors do not go to court, but to the Paris Club, an informal group of governments hosted by the French treasury since $1956 .{ }^{16}$ Russia has been a member since 1997, and has participated in the club's Ukrainian debt restructurings before.

Some market reports suggest that documenting the Yanukovych bailout as a garden-variety eurobond made it easier for Russia to advance the money quickly through its sovereign wealth fund (Box 1) ${ }^{17}$ It had two other advantages. First, because the notes can trade in the private capital markets, Russia can easily exit its Ukrainian investment. Second, contractual links between the Yanukovych notes and Ukraine's other private debt give Russia the power to destabilize Ukraine's private debt stock. For example, default on the Yanukovych notes would count as default under Ukraine's other bonds, and may trigger payments under credit default swap (CDS) contracts on Ukraine (Box 4). It is common for bonds to "cross-default" in this way to other bonds; it is unusual for them to cross-default to public sector credits. The rationale behind segmentation is that private bondholders and government creditors have different motives

\footnotetext{
${ }^{12}$ Corruption by Country/Territory, Ukraine, Transparency International, http://www.transparency.org/country\#UKR DataResearch_SurveysIndices (last visited April 20, 2014).

${ }^{13}$ INT'L FINANCE CORP., THE WORLD BANK, COUNTRY PARTNERSHIP STRATEGY FOR UKRAINE II 41 (2012).

${ }^{14}$ Asset Recovery Workers on the Case of Ukrainian Kleptocrats, NAT'L PUBLIC RADIO, March 6, 2014, http://www.npr.org/2014/03/06/286646514/asset-recovery-workers-on-the-case-of-ukrainian-kleptocrats.

${ }^{15}$ Ukraine's Stolen Assets: A Long, Hard Slog, ECONOMIST, March 5, 2014, http://www.economist.com/blogs/easternapproaches/2014/03/ukraine-s-stolen-assets.

${ }_{17}^{16}$ See Club De Paris, http://www.clubdeparis.org (last visited May 8, 2014).

${ }^{17}$ Ukraine Debt: An Investor's Guide, EUROPE EMERGING MARKETS RESEARCH (J.P. Morgan), March 27, 2014, at 11-12.
} 
and different relationships with the sovereign debtor. ${ }^{18}$ The Yanukovych notes give Russia the benefit of private contract linkages, without the private investors' profit constraints.

\section{Box 1}

\section{Sovereign Wealth Deployed}

Russia bought the Yanukovych notes with money from its sovereign wealth fund, whose stated mission had been to channel oil revenues into public pension savings. It did so in apparent contravention of the fund's stated policy of investing in debt rated AA- or higher. ${ }^{19}$ Ukraine's debt was rated CCC by Standard \& Poors; its highest rating in the preceding five years was B+. The fact that the note purchase violated the wealth fund's investment policy implies political motive.

The fact that the Yanukovych bailout was a political power play is not a big revelation. For the moment, the Russian fund's Ukrainian adventure may be of greatest concern to the Russian citizens whose pensions are at risk. Judging from the opinion polls, they may not mind. ${ }^{20}$

However, such blatantly political deployment of sovereign wealth is embarrassing for the emerging international regime governing sovereign wealth funds. The 2008 Santiago Principles, a voluntary code of conduct agreed among funds from 25 countries, including Russia, were adopted partly in response to accusations of political investment. ${ }^{21}$ The rhetoric surrounding the principles and the International Forum on Sovereign Wealth Funds paint the funds as commercial investment vehicles, aspiring to market and technocratic credibility, free of domestic political control. The principles commit member funds to disclose political investment, although they do not strictly prohibit it. ${ }^{22}$ Russia's use of its wealth fund to prop up a political ally is not a breach, but it runs counter to the motivation behind the principles, and is surely awkward for those arguing that sovereign wealth funds are just another bunch of commercial actors.

\footnotetext{
${ }^{18}$ Sovereigns that spend years in arrears to the Paris Club might scrupulously service their bonds. Bondholders whose goal is to get paid would not want to trigger a default if they think that the sovereign debtor's default on the Paris Club would free up money to pay them.

${ }^{19}$ International Forum on Sovereign Wealth Funds, Members Information, Russia, at http://www.ifswf.org/members-info.htm\#rus (last accessed on April 21, 2014).

${ }^{20}$ See Alec Luhn, Russian Opinion Divided over Seizure of Crimea but Majority Likely to Back Putin, GUARDIAN, March 3, 2014, http://www.theguardian.com/world/2014/mar/03/russian-opinion-split-crimea-ukraine-most-backputin

${ }^{21}$ See Edwin M. TRUMAN, PETERSON InSTITUTE FOR INT'L ECON., IMPLEMENTATION OF THE SANTIAGO PRINCIPLES FOR SOVEREIGN WEALTh Funds: A PROGRESS REPORT 2 (2013); AlliE E. BAGNALl \& EDWIN M. TRUMAN, PETERSON INSTITUTE FOR INT'L ECON., IFSWF REPORT ON COMPLIANCE WITH THE SANTIAGO PRINCIPLES: ADMIRABLE BUT FLAWED TRANSPARENCY 1 (2011).

${ }^{22}$ INT'L WORKING GRP. OF SOVEREIGN WEALTH FundS, SOVEREIGN WEALTH FundS GENERALLY ACCEPTED PRINCIPLES AND PRACTICES: SANTIAGO PRINCIPLES 15 (2008). Santiago Principle 19 and commentary to principles 2, 6, 9, 12, and 16 attempt to discourage politically-motivated investment. See id. at 12-22; TRUMAN, supra note 21, at $1-2$.
} 
If Ukraine tried to renegotiate its bonds, Russia could block it, or force other creditors to absorb all the losses. Because Russia holds 100 per cent of the Yanukovych note issue, other creditors cannot use majority amendment (collective action) clauses to make restructuring terms binding on Russia (Box 2). Moreover, Russia’s \$3 billion stake could easily keep Ukraine from reaching the minimum creditor participation threshold typically required for a restructuring to proceed. Russia's direct holdings are 14 per cent of the outstanding principal of government and government-guaranteed foreign bonds, or about 17 per cent not counting the guarantees — and over one-third of the principal maturing through 2016. Holdings by state-owned and captive creditors would raise the numbers considerably. In sum, Russia holds the veto over any marketbased debt restructuring or reprofiling that Ukraine might want to undertake.

\section{Box 2}

\section{Collective Action Problems and Collective Action Clauses}

A government that seeks to restructure its bonds can ask the creditors to amend its debt contracts, or to exchange their bonds for new ones with a more favorable payment profile. Whether the debtor seeks a deep principal reduction or a modest rescheduling of payments, the process is the same. The success of the operation depends on all or most creditors going along with the new terms.

A creditor who refuses to amend or hand in its old contracts can sue for full payment. This has led to concern on the part of the IMF, the Paris Club, and others that "holdout" creditors would block or free ride on restructurings. Other creditors would refuse to participate for fear that their concessions benefit the holdouts; they too would demand to be paid in full. Such creditor collective action problems provide an important rationale for individual and corporate bankruptcy. There is no bankruptcy for sovereign governments. ${ }^{23}$

Absent bankruptcy, holdout creditors can be partly neutralized with contract provisions that allow a majority of creditors (ranging from 50 to 85 per cent) to bind the dissenting minority. Once bound to the new terms, creditors cannot sue on the original contract. Such "collective action clauses" (CACs) have long been customary in English-law bonds, including Ukraine's.

Ukraine can normally amend any of its foreign bonds with the consent of creditors holding just over half of the outstanding principal: three-quarters of a two-thirds quorum at a bondholder

\footnotetext{
${ }^{23}$ See generally Kenneth Rogoff \& Jeromin Zettelmeyer, Bankruptcy Procedures for Sovereigns: A History of Ideas,
} 1976-2001, 49 IMF Staff Papers 470 (discussing the history of proposals for sovereign bankruptcy). 
meeting. ${ }^{24}$ Ukraine's bonds do not provide for aggregated voting, which would allow creditors across different bond issues to vote on amendment. Aggregation terms are still rare in foreign sovereign bonds; those that exist allow creditors holding over a third of any bond issue to force that issue out of the restructuring.

Because Russia holds 100 per cent of the Yanukovych notes, it can be certain of holding out. CACs are irrelevant to it-with or without aggregation.

The power of CACs to block holdout lawsuits is often exaggerated. Although Russia's 100 per cent stake in Ukraine's bond is an outlier, it is common for creditors to buy blocking positions in a single bond issue - particularly a small one, trading at a deep discount — and prevent that issue from being amended. For example, when Greece restructured its bonds in 2012, more than half of its English-law bonds with CACs were able to drop out of the bond exchange. ${ }^{25}$ These bonds continue to be paid on schedule.

One way to overcome holdouts is to hold a single stock-wide restructuring vote, as Greece did with its Greek-law bonds. Individual bond series cannot drop out in this scenario if a high enough majority of the remaining bondholders votes in favor of a restructuring. This mechanism was introduced retroactively by statute in Greece. Recent reforms supported by the IMF and the International Capital Market Association would introduce stock-wide aggregated voting by contract. Ukraine has no such aggregation provisions.

Two unusual terms in the Yanukovych notes give Russia yet more control over Ukraine's debt outcomes. First, unlike all other debt issued or guaranteed by the Ukrainian government, these notes promise to keep government and guaranteed debt under $60 \%$ of Ukraine's nominal GDP. ${ }^{26}$ Ukraine might find itself in debt default simply because its economy collapses, say, thanks to losing territory, new trade barriers with Russia, or civil unrest. Put differently, the bond contracts boost Russia's economic influence over Ukraine as it chips away at the denominator of the debt/GDP fraction. The debt/GDP term could also make the Yanukovych notes more attractive to private investors in the secondary market, since it allows the note holders to demand payment ahead of other creditors, whose bonds do not have the clause. As a result, Russia might fetch a higher price for the Yanukovych notes than a private investor selling a comparable Ukrainian eurobond.

\footnotetext{
${ }^{24}$ Quorum at postponed meetings goes down to 1/3. Ukraine's bond disclosure specifies the quorum, but not the required supermajority; 75 per cent is common in the London market. (Allen \& Overy 2014)

${ }^{25}$ Jeromin Zettelmeyer et al., The Greek Debt Restructuring: An Autopsy 14 n.24 (Peterson Institute for Int'1 Econ., Working Paper No. 13-8, 2013) available at http://www.iie.com/publications/wp/wp13-8.pdf.

${ }^{26}$ See Ukraine Prospectus, supra note 2, at 28 ("Debt Ratio").
} 
Russia also has the right to accelerate the notes if Ukraine fails to pay any entity "controlled or majority-owned" by Russia. ${ }^{27}$ This provision, unique to the Yanukovych notes, may have been intended to cover debt to Gazprom. When the notes were issued, Russia was already claiming billions in arrears under contracts between Naftogaz and Gazprom; some but not all are disputed.$^{28}$ Depending on how the clause is interpreted, the Yanukovych notes might be callable at any time. ${ }^{29}$

The debt/GDP and cross-default clauses in Russia's financing for Yanukovych, along with its two-year maturity, are consistent with Russia's reported intent to keep Ukraine "on a short leash. ${ }^{30}$ Russia used the private contract form under English law to take maximum advantage of the prevailing international regime for sovereign debt management, protecting its financial and political interests, and increasing its leverage over Ukraine, its private and public creditors.

${ }^{27}$ See id. at 27, 31 ("Relevant Indebtedness," "Events of Default-Indebtedness of Ukraine").

${ }^{28}$ Ukraine claims that it does not owe the money because it never took delivery of the gas; it contests the "take or pay" promise. See id. at 16.

${ }^{29}$ At least two alternative readings would be more favorable to Ukraine. First, any arrears are likely owed by Naftogaz, not the government directly. However, the bond language appears to cover a broad range of guarantees and indemnities given by Ukraine. While the gas contracts between Russia and Ukraine are not public, Ukraine has frequently recapitalized Naftogaz to enable payments to Russia. Second, the notes are held by the Russian sovereign wealth fund, not Russia directly. The National Wealth Fund is not the majority-owner of Gazprom. However, if the National Wealth Fund has no distinct personality from the Russian government, the clause would still cover Gazprom. On the other hand, if Russia sells all or part of its holdings, private buyers that do not own or control Gazprom may not be able to invoke the clause.

${ }^{30}$ Kathrin Hille, Ukraine bailout could derail Putin's drive to boost Russian economy, FinANCIAL TIMES, Dec. 18, 2013, http://www.ft.com/intl/cms/s/0/3b3db13c-67e3-11e3-a905-00144feabdc0.html\#axzz313qckIHW. 


\section{Odious Outcasts}

Could Ukraine repudiate the Yanukovych notes on the grounds that Russia's loan was illegitimate and oppressive?

A hundred years ago, the need to collect on sovereign debt for private creditors justified invasions. ${ }^{31}$ Over the course of the $20^{\text {th }}$ century, formal separation of politics and commerce became the trend in sovereign lending and borrowing. ${ }^{32}$ The modern regime for sovereign debt management is based on economic necessity, normally established as part of the IMF program, to the exclusion of politics and justice. Russia's holdings of Ukrainian debt challenge the prevailing regime.

An alternative theory holds that debt is "odious" to the state when a government borrows without the consent of the people and not in their interest. ${ }^{33}$ Odious Debt would compel governments to default on illegitimate debt even if they could pay it. Odious Debt has repeatedly captured academic and civil society imaginations. However, it has failed to alter existing debt restructuring institutions.

In 2014, bondholders can and do sue governments in foreign courts. Sovereign debtors renegotiate private bank loans in law firm conference rooms and restructure bonds in securities offerings, using market-based transactional techniques. Government-to-government debt is dealt with in a separate forum, under separate rules, loosely linked to private debt outcomes. Questions of political legitimacy lurk awkwardly in the background for cases like Iraq and Vietnam.

Since 1997, nineteen countries have restructured their bonds, with over $90 \%$ of their creditors participating. Four of the nineteen had to restructure twice in less than a decade. Thirteen of the nineteen, including Ukraine, restructured bonds owed to foreigners. In the same period, half a dozen, including Ukraine, restructured foreign bank loans and supplier credits. ${ }^{34}$ In all but one of

\footnotetext{
${ }^{31}$ See generally Faisal Z. Ahmed et al., Lawsuits and empire: On the Enforcement of Sovereign Debt in Latin America, 73 LAW \& CONTEMP. PROBS. 39 (2010) (discussing "gunboat diplomacy" in Latin America).

${ }^{32}$ See generally Mark C. Weidemayer, Sovereign Immunity and Sovereign Debt, 2014 U. ILL. L. REV. (forthcoming 2014). But see Louis A. Pérez, Jr. \& Deborah M. Weissman, Public Power and Private Purpose: Odious Debt and the Political Economy of Hegemony, 32 N.C. J. INT'L L. \& COM. REG. 699, $742-45$ (discussing how American political interests affected the American response to Costa Rica's default).

${ }^{33}$ The theory was distilled from earlier doctrines and state practice in the 1920s by a Russian émigré scholar in Paris. According to Alexander Sack, "If a despotic power incurs a debt not for the needs or in the interest of the State, but to strengthen its despotic regime, to repress the population that fights against it ... this debt is odious for the population of all the State. ..."Odious" debts, incurred and used for ends which, to the knowledge of the creditors, are contrary to the interests of the nation, do not compromise the latter ... The creditors have committed a hostile act with regard to the people; they cannot therefore expect that a nation freed from a despotic power assume the "odious" debts, which are personal debts of that power." See Sarah Ludington \& Mitu Gulati, A Convenient Untruth: Fact and Fantasy in the Doctrine of Odious Debts, 48 VA. J. INT'L L. 595, 597 (2008) (citing A.N. SACK, LES EFFETS DES TRANSFORMATIONS DES ETATS SUR LEURS DETTES PUBLIQUES ET AUTRES OBLIGATIONS FINANCIERS 46-61 (1927)).

${ }^{34}$ See Elena Duggar, Moody's Investors Service, New Evidence on the Role of Holdout Creditors in Sovereign Debt Restructurings (May 17, 2013), available at https://csis.org/files/attachments/130520_Duggar_Presentation_0.pdf; Das et al., supra note 6, at 37 tbl.5; Sturzenegger \& Zettelmeyer, supra note 5, at 121.
} 
these cases, debt relief was justified in economic terms. Countries restructured either because they had no foreign currency to pay the debt coming due in the near term, or because their debt had been judged unsustainable in the medium term: even with economic reforms and new financing, the debt would keep growing, outpacing their capacity to repay.

The sole exception was Ecuador, which launched a bond buy-back offer in 2008, threatening default because a presidential audit commission "found significant indications of illegality and illegitimacy." 35 Allegations of illegitimacy ranged from failure to obtain proper authorizations to hostile interest rate hikes by the U.S. Federal Reserve; they were and continue to be contested. ${ }^{36}$ Nonetheless, Ecuador secured nearly 70 per cent relief on the debt in the exchange. ${ }^{37}$ The IMF pointedly refused to intervene, citing a policy of staying out of politics. ${ }^{38}$

The Ecuador exception proved the rule: despite a rich record of corruption, military intervention, and human rights abuse, governments seeking debt relief in recent decades have stuck to arguing that they cannot afford to pay. Even post-apartheid South Africa and post-Saddam Iraq specifically refused to invoke Odious Debt. ${ }^{39}$ This may have something to do with the fact that Odious Debt as a doctrine of law is cumbersome to invoke; it is also true that creditors and debtors have limited incentives to make it better.

Odious Debt is narrow, unwieldy and uncertain. In the original formulation, it applies to state succession (for example, territorial break-up), but not to a change in government. The present scope and force of the doctrine are unclear because scholars disagree about the legal significance of historical precedent, ranging from the Fourteenth Amendment of the U.S. Constitution (repudiating Confederate debts in 1868) to Germany's refusal to assume Austrian debt in $1938 .{ }^{40}$ They also disagree about the meaning of odiousness: is it limited to money used by tyrants to torture and oppress? What about kleptocracy? ... or wasteful spending by elected officials ${ }^{41}$

\footnotetext{
35 The Republic of Ecuador, Noteholder Circular, April 20, 2009, available at http://blogs.reuters.com/felixsalmon/files/2009/04/noteholder-circular-goe-bond-offer.pdf at i-iv (Letter from the Finance Minister)

${ }^{36}$ See Arturo C. Porzecanski, When Bad Things Happen to Good Sovereign Debt Contracts: The Case of Ecuador, 73 LAW \& CONTEMP. Probs. 251, 261 (2010); Center for Global Development, Preventing Odious Obligations: A New Tool for Protecting Citizens from Illegitimate Regimes (2010) at 7.

${ }^{37}$ See Das, supra note 6, at 37 tbl.5.

${ }^{38}$ See Int'1 Monetary Fund, Transcript of Regular Press Briefing by Caroline Atkinson, Director, External Relations Department (Dec. 18, 2008) available at http://www.imf.org/external/np/tr/2008/tr121808.htm ("We understand that Ecuador's decision to default on these bonds is based on a dispute about legal validity rather than debt sustainability, and of course we don't take sides on the merits.").

${ }^{39}$ See Center for Global Development, supra note 36; Ali Allawi, Why Iraq's Debt Deal Makes Sense, EUROMONEY, Sept. 2005, at 213.

40 See Robert Howse, United Nations ConfEREnCE On Trade AND DEVElopment, The CONCEPT OF Odious Debt In Public InTERnational LaW (2007); Tai-Heng Cheng, Renegotiating the Odious Debt Doctrine, 70 L. \& Contemp. Probs. 7 (2007).

${ }^{41}$ See generally Symposium, Odious Debt: Exploring the Outer Limits of Sovereign Debt Relief, 32 N.C. J. Int'1 L. \& Com. Reg. 605 (2007) (collections of legal scholarship responding to the revival of odious debt doctrines after the fall of Saddam Hussein); Symposium, Odious Debts and State Corruption, Law \& Contemp. Probs., Summer 2007, at 1; Symposium, Odious Debts and State Corruption, Law \& Contemp. Probs., Autumn 2007, at 1.
} 
Then there is the institutional gap. Absent sovereign bankruptcy, there is no central place to decide odiousness. Debt audit commissions established after the fall of a despotic regimealongside truth and reconciliation commissions for human rights abuses - may be the most logical and morally satisfying institutional home for Odious Debt. ${ }^{42}$ These have not taken root, perhaps because sifting through a mountain of debt contracts is time-consuming and expensive, while new governments and their creditors are often eager to get on with new borrowing and economic recovery. With no new institutions, Odious Debt could act as an equitable limit on the debtor's duty to repay - but it would have to be developed and applied by the courts presiding over debtor-creditor lawsuits in the current fragmented system. ${ }^{43}$ This would require debtors to invoke Odious Debt as grounds for nonpayment. They have not done so.

Public and private creditors have successfully preempted calls for relief of illegitimate debt by offering relief for unsustainable debt. New governments that inherit debt from tyrants and kleptocrats face the choice of relatively quick and certain relief on economic grounds, or a long, contentious and uncertain battle for relief on political grounds. Although the trade-off might be worth it for some, it is unsurprising that so few try. Government creditors in particular have been reluctant to endorse nonpayment of politically motivated debt, since this would undermine much of their own lending. Thus while the United States in 2003 might have been happy to support Iraq's repudiation of Saddam Hussein's debt on the grounds that he was a murderous tyrant, U.S. officials in 1993 were less enthusiastic about Vietnam's refusal to repay military debt thinly disguised as agricultural credits in $1971 .^{44}$

In sum, the existing regime for foreign sovereign borrowing and restructuring remains anchored in economic need. Debt negotiations take place in multiple venues following the parameters of the IMF program. Fairness and legitimacy are shut out of the process, because the participants have few incentives to invoke them. This regime is unlikely to work for Ukraine. First, Russia's contracts give it the capacity to trigger a debt crisis and block any restructuring that Ukraine might need as a result. Second, paying Russia while it fights Ukraine would be unjust, even if Ukraine could afford it.

\footnotetext{
${ }^{42}$ Robert Howse \& Ruti Teitel, Debt, Dictatorship, and Democratization, PROJECT SyndiCATE (April 4, 2011) http://www.project-syndicate.org/commentary/debt--dictatorship--and-democratization.

${ }^{43}$ See OdetTe Lienau, Rethinking Sovereign Debt: Politics, Reputation, And Legitimacy (2014); Howse, supra note 40, at 6; Lee C. Buchheit et al., The Dilemma of Odious Debts, 56 DuKE L.J. 1201.

${ }_{44}$ Marian Nash, Contemporary Practice of the United States Relating to International Law, 91 AM. J. INT'L L. 697 (1997).
} 


\section{A Sanctions Alternative}

Ukraine's allies and benefactors face a stark choice. The path of least resistance is to use public money to reward Russia's arbitrage and add to Ukraine's debt stock. The alternative - a debt restructuring, however mild — would have to reckon with Russia and creditors controlled or influenced by Russia. These creditors may not respond to market incentives. On the other hand, paying them in full might feel unfair and politically risky, potentially undermining popular support for aid to Ukraine and the multilateral institutions vital to its recovery. ${ }^{45}$

Ukraine could simply refuse to pay the Yanukovych notes. It is unlikely that Russia would sue to enforce them in an English court. More plausibly, Russia might sell the notes to a private investor. In the best possible case scenario, the new buyer would act just like any other commercial creditor - even if it might pay Russia more for the extra protection embedded in the debt/GDP and cross-default clauses. In the worst case, the buyer could be a bank or a firm doing Russia's bidding. If the new private creditor triggers a default and sues to collect, Ukraine could try to defend by invoking Odious Debt; however, a court is unlikely to punish the new investor for Russia's "short-leash" support of Yanukovych. At a minimum, failure to pay could damage Ukraine's market reputation and, through the various contract linkages, cause a string of disruptions - which would play into Russia's hands.

As an alternative to unilateral repudiation by Ukraine, the United Kingdom could enact legislation making the Yanukovych notes unenforceable under English law. An Act of Parliament would limit Russia's capacity to disrupt Ukraine's debt service and any future debt negotiations. (Box 3) Commercial investors would have no interest in unenforceable contracts; as a result, Russia would find it hard to rescue its investment by selling the notes in the capital markets. Ukraine would suffer no reputational fallout, since the action would be taken by the United Kingdom. Ukraine would retain the option to pay the notes as part of a political settlement, but would be in a better bargaining position getting there. Future lenders would be on notice that using the capital markets to control neighboring countries could backfire.

A law targeting Russia's holdings of Ukrainian bonds would build on recent European and U.K. measures to shield Iraq and heavily indebted poor countries from debt collection, as well as a contract sanctions proposal from the Center for Global Development Working Group on the Prevention of Odious Debt (the CGD Group). It is also in line with the contract sanctions consultation document issued earlier this year by the U.K. Foreign and Commonwealth Office

\footnotetext{
${ }^{45}$ Some U.S. legislators used Ukraine's debts to Russia to argue against U.S. support for the IMF. Ed O'Keefe, Who voted against U.S. aid to Ukraine?, WASHINGTON POST, March 27, 2014, http://www.washingtonpost.com/blogs/the-fix/wp/2014/03/27/who-voted-against-u-s-aid-to-ukraine//?print=1; Press Release, Ted Cruz, Cruz, GOP Senators, Object to IMF Expansion in Ukraine Aid Package (March 21, 2014) available at http://www.cruz.senate.gov/?p=press_release\&id=1046.; Press Release, Ted Cruz, Sen. Cruz: Senate Democrats Hold Ukraine Aid Hostage to Politics (March 13,2014) available at http://www.cruz.senate.gov/?p=press_release\&id=1021; Pat Toomey, Sen. Toomey questions Secretary Lew at Budget Committee Hearing, YouTuBE (March 12, 2014), http://www.youtube.com/watch?v=6QLPG_8K4bM\&list=UUDUM4FFU1p-_YuHqmBglyXw
} 
(FCO). ${ }^{46}$ The proposed law would be preferable to traditional financial sanctions, and would address Russia's contract arbitrage in Ukraine more directly than these other measures.

First, making debt unenforceable is less intrusive than freezing assets and blocking payments. ${ }^{47}$ At this writing, major global financial institutions are refusing to move money for sanctioned Russian clients and counterparties, potentially breaching prior contractual commitments. ${ }^{48}$ As noted earlier, Ukraine would retain the capacity to pay Russia; Russia would merely lose recourse to the English courts and the negotiating leverage from holding a big block of Ukrainian eurobonds. As proposed, the law would only apply to the enumerated contracts, and could include a sunset provision, restoring access to the courts at a later date or if certain conditions are met. It would be a tailored response to the use of private capital market contracts for political control.

\section{Box 3}

\section{Debt and Dismemberment: The Law of State Succession}

If Ukraine were to split, it would be logical to apportion its foreign debt using a formula that accounts for some mix of assets, territory, population, and the original use of proceeds. ${ }^{49}$ The break-ups of Czechoslovakia and Yugoslavia led to apportionment, but without the scientific formula. In contrast, Russia kept all the foreign debt of the Soviet Union, along with its foreign assets (despite initial protests from Ukraine over its interest in the Black Sea fleet).

Notwithstanding the history of territorial splits spanning centuries, the law of state succession in debt and assets is incredibly sparse. State practice is diverse and inconsistent, with factors weighing differently in different cases, creditors playing a role in some cases but not others, complex and contentious settlement negotiations spanning decades, all culminating in only the vaguest of principles to guide successor states. ${ }^{50}$

\footnotetext{
${ }^{46}$ U.K. Foreign \& Commonwealth Office, Contract Sanctions: A Consultation (February 14, 2014).

${ }^{4}$ See Libyan Arab Foreign Bank v. Bankers Trust Co., [1989] Q.B. 728 (Eng.).

${ }^{48}$ See Kathrin Hille, Russia Looks for Economic Self-Reliance, Financial Times (April 22, 2014), http://www.ft.com/intl/cms/s/0/ee5d9120-ca2f-11e3-bb92-00144feabdc0.html\#axzz313qckIHW. A recent English case held that an asset freeze does not automatically excuse the target's contract counterparty from performing under the contracts, at least not when they might have been issued a license. See Melli Bank Plc. v. Holbud Ltd., [2013] EWHC (Comm) [1506].

${ }^{49}$ For example, a World Bank project loan for the sole benefit of a particular locale.

${ }^{50}$ See generally, Tai-Heng Cheng, State Succession and Commercial Obligations (2006); Tai-Heng Cheng, Why New States Accept Old Obligations, 2011 U. Ill. L. Rev. 1 (2011); Volinka Reina, Iraq's Delictual and Contractual Liabilities: Would Politics or International Law Provide for Better Resolution of Successor State Responsibility?, 22 Berkeley J. Int'1 L. 583, 584 (2004); Guido Acquaviva, The Dissolution of Yugoslavia and the Fate of Its Financial Obligations, 30 DENV. J. InT'L L. \& POL'Y 173 (2002); Paul Williams \& Jennifer Harris, State Succession to Debts and Assets: The Modern Law and Policy, 42 HARV. INT'L L.J. 355 (2001).
} 
The 1983 Vienna Convention on Succession of States in Respect of State Property, Archives and Debts has only seven signatories to date (including Ukraine but not Russia) — so few that it is not even in force, with bleak prospects going forward. Even if the convention were effective, it would be of little help. It provides that debt should be allocated by mutual agreement. ${ }^{51}$

Thus the legal instrument that might have been a natural vehicle for the public international law of Odious Debt offers no meaningful guidance or support whatsoever for Ukraine. One thing is certain: if Ukraine broke up, it would have to negotiate its debt allocation with the pro-Russian regions, with Russia holding some of the better cards in the form of its debt contracts.

Second, making some of Ukraine's eurobonds unenforceable would not require multilateral action, because they are governed by English law. It would be easier than shielding all of Iraq's oil and gas proceeds from attachment by commercial creditors - as the European Union, the United States, and others had done pursuant to U.N. Security Council resolution 1483 in May of 2003. ${ }^{52}$ Multilateral action was essential then because Iraqi oil and gas could be seized by creditors in any number of jurisdictions. In contrast, primary legislation in the United Kingdom would be sufficient to deal with the Yanukovych notes. Russia's U.N. Security Council veto would not matter.

Nevertheless, as the CGD Group aptly stressed, unilateral contract sanctions by major financial jurisdictions can look like illegitimate power plays. Moreover, unilateral action may lead to abusive lending migrating elsewhere, and a competitive disadvantage for the United Kingdom, if legitimate transactions move offshore for fear of future sanctions - a point hammered home in responses to the FCO consultation. ${ }^{53}$ Action by the U.K. alone may be expedient in crisis, but suboptimal in the long run. It would be important for other financial centers and other countries from across the income spectrum to issue public statements of support for the U.K. measures, and to implement similar ones in the medium term, to maximize the legitimacy and effectiveness of the proposed law. ${ }^{54}$

\footnotetext{
${ }^{51}$ Vienna Convention on Succession of States in Respect of State Property, Archives and Debts, opened for signature April 18, 1983, U.N. Doc. A/CONF.117/14, 22 I.L.M. 3066 (1983) ("When part of the territory of a State is transferred by that State to another State, the passing of the State debt of the predecessor State to the successor State is to be settled by agreement between them.").

${ }^{52}$ See Council Common Position (EC) No. 3003/495/CFSP of 7 July 2003, art. 2, 2003 O.J. (L 169) 1. This order expired on June 30, 2011. See Council Decision 2011/100/CFSP of 14 February 2011, 2011 O.J. (L 41) 1. See also Exec. Order No. 13,303, 68 Fed. Reg. 31931 (May 22, 2003).

${ }^{53}$ See e.g., General Council of the Bar of England and Wales, Bar Council Response to the Contract Sanctions Consultation Paper (March 17, 2014); cf. Eric J. Pan, Why the World No Longer Puts Its Stock in Us (Cardozo L. Stud. Research Paper No. 176, 2006), available at http://papers.ssrn.com/sol3/papers.cfm?abstract_id=951705.

${ }^{54}$ Not all countries would require new legislation to adopt the proposed measures; for example, the United States has broadly framed sanctions legislation that gives the President considerable authority to impose specific sanctions. See 12 U.S.C. § 95(a); CENTER FOR GLOBAL DEVELOPMENT, supra note 36.
} 
Third, private creditors should support sanctions to curb Russia's outsize influence over Ukrainian debt. This would be in contrast to the 2010 act of Parliament capping creditor collections from the world's poorest countries, enacted over protests from capital markets participants. ${ }^{55}$ The U.K. Debt Relief (Developing Countries) Act 2010 responded to litigation against Zambia and Liberia, where a few private firms recovered large sums from countries eligible for up to $90 \%$ debt relief under the multilateral Heavily Indebted Poor Countries (HIPC) initiative. ${ }^{56}$ These firms free-rode on taxpayer concessions, and diverted scarce resources from basic human needs. In response, the 2010 law said that private creditors may not collect proportionally more than government creditors in lawsuits against HIPC countries. The law only applies to debt contracted before its initial enactment on June 8, 2010. Unlike that law, which sought to enforce burden-sharing between public and private creditors, the law proposed here would target a single public creditor-Russia - to prevent it from free-riding on private creditor concessions and destabilizing Ukraine's debt.

Fourth, the law proposed here would operate similarly to the CGD Group and FCO contract sanctions: all three would make contracts unenforceable in English courts. However, because the CGD and FCO contract sanctions would be purely prospective, they would not help with Ukraine's debt to Russia. Therefore, the proposed law would be retrospective, like the 2010 act to shield HIPC countries, the immunities for Iraqi oil and gas, and most versions of Odious Debt.

The analytical case for prospective financial sanctions was made by Jayachandran and Kremer in 2006, ${ }^{57}$ adapting legal theories of Odious Debt. They argued that multilateral sanctions denying contract enforcement going forward would avoid some of the problems of Odious Debt in its original formulation. They would give creditors certainty, while reducing the borrowing capacity of sanctioned regimes, and the scope for ex post bias on the part of the sanctioning authority. ${ }^{58}$ The CGD Group took this analysis further, proposing multilateral compacts to make a wider range of commercial contracts entered into by repressive or corrupt regimes "nontransferable" to their successors. ${ }^{59}$

Their argument is persuasive and the proposal is sound; however, Russia's arbitrage of the sovereign debt regime in Ukraine shows its limitations. The case against paying Russia seems compelling now that its military is engaged in Ukraine; it was not nearly as compelling before the troops shot unarmed demonstrators in February, maybe not before the Russian takeover of

\footnotetext{
${ }^{55}$ David Oakley, UK to act on vulture fund court cases, THE FINANCIAL TIMES (February 26, 2010)

${ }^{56}$ See Donegal Int'l Ltd. v. Zambia, [2007] EWHC (Comm) 197, [2007] 1 Lloyd's Rep. (Eng.); Thomas Laryea, Donegal v. Zambia and the Persistent Debt Problems of Low-Income Countries, 73 L. \& CONTEMP. PROBS. 193 (2010). The lawsuit against Zambia originated with an agricultural credit from Romania that would have been restructured in the Paris Club. The original credit was unenforceable in English courts. Romania sold the loan to a private investor, who convinced Zambian officials to turn it into an enforceable contract under English law. Id. 57 See Seema Jayachandran \& Michael Kremer, Odious Debt, 96 AM. ECON. REV. 82 (2006).

58 They also argued that loan sanctions are more efficient than trade sanctions in the long term.

${ }^{59}$ See CEnTER FOR Global DEVElopMent, supra note 36. The CGD Group proposal focused in particular on debt and extractive industry contracts.
} 
Crimea. Contracts that give the creditor discretion, to be exercised in good faith, might be tolerable in peace time, but not when the contracting parties go to war.

Furthermore, prospective contract sanctions hinge on the identity of the counterparties (despotic borrowers), while in the case of Russia and Ukraine, the form and terms of the debt contracts are a problem distinct from Yanukovych's corruption. ${ }^{60}$ These terms were not public before they were agreed and posted on the Irish stock exchange website in December 2013. It would have been hard to specify the debt/GDP or cross-default clauses as problematic in advance. On the other hand, sanctioning all of Russia's commercial dealings with Ukraine was implausible then - and continues to be implausible and undesirable at this writing, in light of Ukraine's continued dependence on trade with Russia.

A more radical way to stop governments from using private debt contracts for geopolitical gain is to make all such contracts unenforceable ex ante, on the theory that they might become abusive if the political winds change. This would fundamentally redefine large swaths of global finance, for example, making it impossible for central banks to buy foreign government debt in the secondary market to manage currency reserves, and would similarly affect export finance and sovereign wealth fund investments. It would also encourage workarounds through private proxies.

In practice, a true separation between finance and politics would be undesirable and unachievable. What is needed instead is a way to detect and deter abuse in an institutional framework designed as if the two spheres were separate, and is therefore prone to arbitrage.

The resulting options are uncomfortable. There is no way of avoiding ex post sanctions to address contract arbitrage, and thus no way of avoiding accusations of bias, power politics, commercial uncertainty and interference with contracts. This is the basic predicament of sanctions and Odious Debt alike. ${ }^{61}$ With bond contracts, there is also the risk that sanctions might trigger the very disruption they are designed to preempt. (Box 4) Nevertheless, if the sanctions are narrowly drawn and justified by specific reference to obnoxious contract terms and behavior to be deterred, they are more likely to be perceived as legitimate and gain support from a broad set of countries and market participants. They are also more likely to have a sound effect on lending going forward: debtors and creditors would be on notice that certain kinds of terms, lending arrangements, and debt collection strategies are inconsistent with international norms, and may not be enforced.

\footnotetext{
${ }^{60}$ If Yanukovych had a change of heart, turned to the West, and ended up in conflict with Russia like the current government, the notes would still present a problem because their terms give Russia the ability to destabilize Ukraine's private debt.

${ }^{61}$ In an earlier article on Odious Debt, I argued for subordinating some government-to-government debt on the grounds that it is less like debt, with its unconditional expectation of repayment, and rather more like an equity investment in the political fortunes of the borrowing government. Although such a rule would have obvious incentive effects going forward, I had envisioned that it would be applied ex post, as part of a restructuring. Anna Gelpern, Odious, Not Debt, 70 LAW \& CONTEMP. ProBs 81 (Summer 2007)
} 


\section{Box 4}

\section{Default, Cross-Default, and Credit Default Swaps: The Contract Consequences of Sanctions}

It is a default under the terms of the Yanukovych notes, and all of Ukraine's other foreign bonds, if they become invalid or unenforceable, or if Ukraine contests their validity. In theory, Russia could demand full payment under the notes if the U.K. enacts the legislation proposed here, or if Ukraine were to invoke Odious Debt. With the legislation in place, Russia could not sue to enforce this contract term; however, its demand for full payment could conceivably trigger crossdefault under Ukraine's other bonds.

This scenario is far-fetched for two reasons. First, the other creditors would have no incentive to call their bonds under the circumstances - not paying Russia would not be an early sign of distress (the rationale for cross-default clauses), but rather a way to preserve Ukraine's scarce resources to pay commercial creditors acting in good faith. Second, a court faced with a creditor trying to cross-default to unenforceable debt might question that creditor's good faith, and refuse to enforce the cross-default whose sole effect would be to push the debtor into insolvency without improving the creditor's repayment prospects. It is hard to predict in advance how a court might come out in such a case, invoking principles of equity and lender liability, which leave considerable room for judicial discretion. Nevertheless, with no commercial upside and some legal downside for private creditors using the cross-default, the risk to Ukraine is small.

Credit Default Swap (CDS) contracts on Ukrainian debt present a harder question: it is likely that a default or restructuring of the Yanukovych notes would trigger obligations to pay under the CDS. However, it is less certain that an act of the U.K. Parliament would do the same.

Under a CDS contract, a protection seller promises a protection buyer to take on the credit risk of an underlying obligation in exchange for periodic payments. If a "credit event" such as a debt default occurs during the term of the contract, the seller must pay the buyer for the loss in value of the obligation. At this writing, the outstanding gross notional amount of CDS contracts on Ukraine was just over \$19 billion. Because some market participants are both buyers and sellers of protection, the net notional amount of outstanding CDS contracts on Ukraine is much lower, at approximately $\$ 579$ million. $^{62}$

CDS contracts are highly standardized under the auspices of the International Swaps and Derivatives Association (ISDA). As a result, the terms of CDS of Ukraine are well-known in the market. ${ }^{63}$ Ukrainian CDS cover all its foreign sovereign bonds, but not its loans, ${ }^{64}$ bonds placed

\footnotetext{
${ }^{62}$ DTCC Trade Information Warehouse, Table 6, as of May 2, 2014, at http://www.dtcc.com/market-data/section$1 /$ table-6.aspx. This represents a dramatic decline from $\$ 50$ billion and $\$ 2.5$ billion, respectively, in 2009 . JP Morgan, supra note 17 at 17.

${ }^{63}$ See e.g., JP Morgan, supra note 17.
} 
in the domestic market, or bonds denominated in local currency. While CDS in some markets require that the underlying bond be held by three or more holders, this provision does not apply to Ukraine - which means that the Yanukovych notes, held by Russia alone, are not automatically excluded from the reference pool. Ukrainian CDS contracts trigger upon failure to pay, acceleration, repudiation, moratorium, or a bond restructuring that is "binding on all" the holders of the relevant bond issue (for example, when CACs are used to eliminate holdout creditors). ${ }^{65}$

Refusal to pay, or a claim by Ukraine that the Yanukovych notes were illegitimate might well constitute a repudiation, triggering Ukrainian CDS. In contrast, an act of the U.K. Parliament making the Yanukovych notes unenforceable need not by itself constitute a triggering event, particularly if it does not result from a deterioration of Ukraine's creditworthiness, but rather from concern that Russia would try to bring about such a deterioration for political reasons. ${ }^{66}$

Whether a credit event occurs under CDS contracts is decided by a supermajority vote of an ISDA Determinations Committee for the relevant geographic region, each comprising 15 industry representatives. The committees have some scope for interpretation of ISDA contracts. In the past, they have sought to achieve an outcome that is broadly acceptable to the market and the policy establishment, while hewing close to the text of the contract. ${ }^{67}$

In sum, although there is risk that Ukrainian CDS will trigger if Ukraine chooses not to pay Russia or restructure its debt, they are unlikely to trigger with contract sanctions alone. Perhaps more importantly, with less than $\$ 600$ million likely to change hands in the event of a trigger, CDS should not drive Ukraine's policy choices—-nor those of its allies.

\footnotetext{
${ }^{64}$ It is possible but unlikely that an ISDA Determinations Committee might decide that the notes are a loan in disguise.

652003 ISDA Credit Derivatives Definitions, Article IV.

${ }^{66}$ However, U.K. legislation would not prevent CDS from triggering in the event of a failure to pay or a restructuring binding on all holders, resulting from a deterioration of Ukraine's financial condition. Id., Sec. 4.1.

${ }^{67}$ Anna Gelpern \& Mitu Gulati, CDS Zombies, 13 Eur. Bus. Org. L. Rev. 347 (2012).
} 


\section{Objections and Counters: Tools for a Messy World}

There is a gap in the international financial architecture. Today's fragmented sovereign debt restructuring regime seeks to deliver economic relief but has no space for questions of political legitimacy. At the other extreme, traditional sanctions impose economic pain for political payoff; economic benefit is not part of the equation. The debt sanctions proposed here bridge this gap. They address two important problems that no other policy tool does: the use of debt contracts for political control and hostile acts by a creditor government against the debtor. In addition, debt sanctions can deliver badly needed financing for Ukraine. Nevertheless, they are open to objections.

The most common criticism of contract sanctions also applies to debt sanctions: They interfere with contracts. This criticism misunderstands both debt contracts and traditional sanctions. Debt contracts are routinely invalidated by the courts, rewritten in bankruptcy, and blocked by traditional sanctions. Traditional sanctions by definition interfere with contracts when they forbid delivery of goods or money transfers. Once Ukraine's allies have decided to use sanctions against Russia, they have committed to breaking contracts for political ends, unless they design sanctions specifically to exclude existing contracts. ${ }^{68}$ Debt sanctions are more limited than traditional trade and financial sanctions because they do not prohibit the underlying activity but simply refuse court enforcement.

A related objection is that UK efforts to protect Ukraine's market reputation could backfire against the United Kingdom. A leading financial center cannot disregard contracts willy-nilly and stay leading for long. This is not an argument against debt sanctions but for using them rarely and choosing targets carefully. When sanctions are narrowly crafted (for example, targeting a single unusual bond issued by Ukraine), the benefit of the vast London market would continue to outweigh fear of sanctions for most debtors and creditors. Nevertheless, the United Kingdom would benefit from multilateralizing the initiative.

Another related argument is that unilateral debt sanctions could be circumvented. For example, Russia or someone who buys the bonds from Russia could try to sue outside the United Kingdom. This would not detract from the proposed sanctions. Ukraine would have little to fear from such a judgment if it is uncollectable in the United Kingdom. Suing on English-law bonds in a jurisdiction friendly to Russia would also hold no attraction for mainstream investors, reducing the market value of the bonds.

At the other end of the spectrum, some might press to expand the sanctions beyond the $\$ 3$ billion bond contract with Russia. Including Gazprom arrears and holdings of Ukraine's debt by Russian entities would deliver more relief to Ukraine and would send an even stronger message to Russia. Alternatively, repudiating all debt incurred under Yanukovych would discourage lending

\footnotetext{
${ }^{68}$ For example, recent EU trade sanctions are notable for carving out existing contracts to allow French and German equipment deliveries to Russia.
} 
to corrupt leaders. Such expansive sanctions would be harder to justify and administer. The \$3 billion bond makes a good target because it is particularly objectionable in form and substance and because it is easy to identify. As they gain experience with debt sanctions, the United Kingdom and others could consider criteria for expansion - or decide to reserve the measure for the most egregious debts.

Another criticism would ask what makes speculative private investment betting on a donor bailout of Ukraine morally superior to Russia's bonds. Such investment may raise a burdensharing problem but not necessarily one of illegitimacy and abuse. It can be solved in a conventional debt restructuring based on economic considerations without recourse to sanctions. In turn, debt sanctions are best suited to counter political abuse of debt contracts, which is not confined to government creditors but happens to be salient with Ukraine's debt to Russia. ${ }^{69}$

Finally, there is the awkwardness of a former imperial power unilaterally declaring other countries' contracts illegitimate. The United Kingdom and the United States have both used military force in the past to collect debts and influence their neighbors (Perez and Weissman 2007). Is it legitimate for them to punish Russia for doing the same? This objection has no easy counter. Major financial jurisdictions necessarily project political power. Sanctions are a transparent way to do it. It would obviously be better if sanctions were multilateral, but changing English law is the most practical interim solution.

In sum, debt sanctions lack the moral clarity of forward-looking multilateral contract sanctions and of the more traditional visions of odious debt, where courts or audit commissions sift through a dictator's debts amid the rubble left behind..$^{70}$ Nevertheless, they would fill an institutional gap in international finance, put pressure on Russia, and help Ukraine.

\section{Conclusions}

It all comes back to this - for better or worse, sovereign governments cannot file for bankruptcy. Compounding the problem, the law on state succession thin and uncertain when it comes to debt. There is no court to sift through sovereign debts to decide which are good, which are abusive, and what to do about the in-between - nor to apportion assets and liabilities between Old and New Ukraine, as between Old and New Chrysler, should it come to this. Instead, there is a patchwork of contracts, customs, and institutions, which does a decent job of relieving country

\footnotetext{
${ }^{69}$ If governments were the only ones doing political lending, one could simply close national courts prospectively to their debt contracts and treat them as bets on the survival and prosperity of the borrowing government (Gelpern 2007). This would force debt negotiations into political fora and reduce private market interest in the debt. This approach is impractical in a world where central banks and reserve managers use sovereign bonds as policy instruments; it is also ineffective in a world where private financial firms can easily front for governments in most political lending.

${ }^{70}$ Robert Howse and Ruti Teitel, "Debt, Dictatorship, and Democratization," Project Syndicate, April 4, 2011, http://www.project-syndicate.org/commentary/debt--dictatorship--and-democratization.
} 
debts burdens after they become "unsustainable," or inefficiently high in the judgment of the IMF. In this patchwork, public and private creditors are supposed to occupy different corners and abide by different rules, lightly coordinated and occasionally adjusted to limit free-riding. Politics is implicit and contained.

This system may or may not deliver the right economic outcomes - the right amount of relief in time $^{71}$ - but it is patently unequipped to deal with the politics inherent in sovereign lending and borrowing. Russia's arbitrage of the private contract form to gain political advantage over Ukraine illustrates one consequence of its failure. Whether Russia uses this advantage to further destabilize Ukraine is beside the point. It can.

Denying enforcement to those private debt contracts that are most prone to political abuse- the Yanukovych notes—would help limit Russia's advantage. The U.K. Parliament should enact a law to that effect. Its adverse consequences for Ukraine, the United Kingdom, and the global financial system would be negligible. Beyond Ukraine, including prospective and retrospective contract sanctions in the sanctions repertoire would amount to recognizing of the obvious: private contracts can be used to advance military and political objectives. ${ }^{72}$ When it happens, the contracts should lose their claim to court enforcement.

\footnotetext{
${ }^{71}$ Committee on International Economic Policy and Reform, The Brookings Institutions, Revisiting Sovereign Bankruptcy (October 2013) at http://www.brookings.edu/ /media/research/files/reports/2013/10/sovereign\%20bankruptcy/ciepr_2013_revisitingso vereignbankruptcyreport.pdf.

${ }^{72}$ Louis Perez \& Deborah Weissman, Public Power and Private Purpose: Odious Debt and the Political Economy of Hegemony 32 N.C. J. INT’L L. \& COM. REG. 699 (2007)
} 